visionary foundation than that which rests on peripolar molecules seeing that it rests upon structural facts which cannot be called in question-a theory also which, as will be seen in due time, has this in its favour,-that it will simplify not a little several important problems in physiology。

\section{B. RADCLIFFE}

\section{ICE-MAKING IN THE TROPICS}

$7 \mathrm{HE}$ most marked example of the influence of radiation of heat on temperature is its influence on the production of artificial ice by the natives of India.

The fields in which the ice is made are low, flat, and open; and the ice is produced in large quantities when the temperature of the air is $16^{\circ}$ or $20^{\circ} \mathrm{F}$. above the freezing point ; and the plan followed is an interesting example of accurate observation applied to practical purposes by a people now ignorant of science. The same process has been employed from time immemorial in India with scientific accuracy; and while the theory was explained by Dr. Wells, the practical application was not so well understood; and this first led me to investigate the subject in India. $\downarrow$

The following method is employed by the natives of Bengal for making ice at the town of Hooghly near Calcutta, in fields freely exposed to the sky, and formed of a black loam soil upon a substratum of sand.

The natives commence their preparations by marking out a rectangular piece of ground 120 feet long by 20 broad, in an easterly and westerly direction, from which the soil is removed to the lepth of two feet. This exca. vation is smoothed, and is allowed to remain exposed to the sun to dry, when rice straw in small sheaves is laid in an oblique direction in the hollow, with loose straw upon the top, to the depth of a foot and a half, leaving its surface half a foot below that of the ground. Numerous beds of this kind are formed, with narrow pathways between them, in which large earthen water-jars are sunk in the ground for the convenience of having water near, to fill the shallow unglazed earthen vessels in which it is to be frozen. These dishes are 9 inches in diameter at the top, diminishing to $4 \frac{3}{10}$ inches at the bottom, $1 \frac{3}{18}$ deep, and $\frac{3}{10}$ of an inch in thickness; and are so porous as to become moist throughout when water is put into them.

During the day the loose straw in the bects above the sheaves is occasionally turned up, so that the whole may be kept dry, and the water-jars between the beds are filled with soft pure water from the neighbouring pools. Towards evening the shallow earthen dishes are arranged in rows upon the straw, and by means of small earthen pots, tied to the extremities of long bamboo rods, each is filled about a third with water. The quantity, however, varies according to the expectation of ice-which is known by the clearness of the sky, and the steadiness with which the wind blows from the N.N.W. When favourable, about eight ounces of water is put into each dish, and when less is expected, from two to four ounces is the usual quantity ; but, in all cases, more water is put into the dishes nearest the western end of the beds, as the sun first falls on that part, and the ice is thus more easily removed, from its solution being quicker.

There are about 4,590 plates in each of the beds last made, and if we allow five ounces for each dish, which presents a surface of about 4 inches square, there will be an aggregate of 239 gallons, and a surface of 1,530 square feet of water in each bed.

In the cold season, when the temperature of the air at the ice-fields is under $50^{\circ} \mathrm{F}$, and there are gentle airs from the northern and western direction, ice forms in the course of the night in each of the shallow dishes. Persons

* Essay on Dew, I8I4.

† Experimental Essay; Jour. As. Society, Calcutta, vol. ii, p. So. are stationed to observe when a small film appears upon the water in the dishes, when the contents of several are mixed together, and thrown over the other dishes. This operation increases the congealing process ; as a state of calmness has been discovered by the natives to diminish the quantity of ice produced. When the sky is quite clear, with gentle steady airs from the N.N.W., which proceed from the hills of considerable elevation near Bheerboom, about Ioo miles from Hooghly, the freezing commences before or about midnight, and continues to advance until morning, when the thickest ice is formed. I have seen it seven-tenths of an inch in thickness, and in a few very favourable nights the whole of the water is frozen, when it is called by the natives solidice. When it commences to congeal between two and three o'clock in the morning, thinner ice is expected, called paper-ice ; and when about four or five o'clock in the morning the thinnest is obtained, called flower-ice.

Upwards of two hundred and fifty persons, of all ages, are actively employed in securing the ice for some hours every morning that ice is procured, and this forms one of the most animated scenes to be witnessed in Bengal. In a favourable night upwards of $10 \mathrm{cwt}$. of ice will be obtained from one bed, and from twenty beds upwards of ro tons.

When the wind attains a southerly or easterly direction, no ice is formed, from its not being sufficiently dry; not even though the temperature of the air be lower than when it is made with the wind more from a northern or western point. The N.N.W. is the most favourable direction of wind for making ice, and this diminishes in power as it approaches the due north, or west. In the latter case more latitude is allowed than from the N.N.W. to the north. So great is the influence of the direction of wind on the ice, that when it changes in the course of a night from the N.N.W. to a less favourable direction, the change not only prevents the formation of more ice, but dissolves what may have been formed. On such occasions a mist is seen hovering over the ice-beds, from the moisture over them, and the quantity condensed by the.cold wind. A mist in like manner forms over deep tanks during favourable nights for making ice.

Another important circumstance in the production of ice is the amount of wind. When it approaches a breeze no ice is formed. This is explained by such rapid currents of air removing the cold air, before any accumulation of ice has taken place in the ice.beds. It is for these reasons that the thickest ice is expected when during the day a breeze has blown from the N.W., which thoroughly dries the ground.

The ice-dishes present a large moist external surface to the dry northerly evening air, which cools the water in them, so that, when at $6 \mathrm{I}^{\circ}$, it will in a few minutes fall to $56^{\circ}$, or even lower. But the moisture which exudes through the dish is quickly frozen, when the evaporation from the external surface no longer continues radiative ; a more powerful agent then produces the ice in the dishes.

The quantity of dry straw in the ice-beds forms a large mass of a bad conductor of heat, which penetrates but a short way into it during the day; and as soon as the sun descends below the horizon, this large and powerfullyradiating surface is brought into action, and affects the water in the thin porous vessels, themselves powerful radiators. The cold thus produced is further increased by the damp night air descending to the earth's surface, and by the removal of the heating cause, which deposits a portion of its moisture upon the now powerfully radiating, and therefore cold surface of the straw, the water, and the large moist surface of the dishes. When better radiators of heat were substituted, as glazed, white, or metallic dishes, the cold was greater, and the ice was thicker, and the dishes were heavier in the morning than the common dishes. Any accumulation of heat on their surface from the deposit of moisture is prevented by the cold dry north-west airs which slowly pass over the 
dishes. The wind quickly dries the ground, and declines towards night to moderate airs. The influence of these causes is so powerful that I have seen the mercury in the thermometer placed upon the straw between the dishes descend to $27^{\circ}$, when three feet above the ice-pits it was $48^{\circ}$.

So powerful is the cooling effect of radiation on clear nights in tropical climates, that in very favourable mornings, during the cold season, drops of dew may sometimes be found congealed in Bengal upon the thatched roofs of houses, and upon the exposed leaves of plants. In the evening the cooling process advances more rapidly than could be supposed by one who has not experienced it himself, and proves the justness of his feelings, by the aid of the thermometer. In the open plain on which the ice is made, I have seen the temperature of the air, four feet above the ground, fall from $70^{\circ} 5^{\circ}$ to $57^{\circ}$, in the time the sun took to descend the two last degrees before his setting.

The tropical rains are succeeded by the cold season, when the night is cold, the sky quite clear, and the air becomes a bad conductor of electricity, from the dry northern winds which then prevail. This is proved by the rapidity with which evaporation proceeds, by the dispersion of clouds, and by the more evident proofs which the hygrometer exhibits. During the cold season vegetation proceeds, and electricity continues to be evolved by living bodies, and during their decomposition.

These remarks will enable us to explain the process by which the ice is prepared in Bengal.

Ist. The large quantity of dry straw and moist dishes rapidly become cold, by their powerfully radiating surfaces, at the same time that the large body of dry straw strongly attracts positive electricity, and the descending currents of air deposit moisture in the dishes of water. Hence, during a cold and clear night, with airs from the N.N.W., the cooling process will advance more rapidly in proportion to the non-electric or attractive nature of the body, which, with the radiating power of the surface, regulates the cold and the quantity of dew deposited upon the body.

and. The high and dry situation and free exposure of the ice-fields to the sky, and the absence of all causes which could interrupt the influence of the large body of non-electrics, and the extensive surface of powerful radiating substances, sufficiently accounts for the degree of cold produced in the ice plates; and

3rd. The cool, dry north-west airs slowly pass over the ice-beds, absorbing the accumulation of moisture and of heat, which is given off by the liquefying of a large quantity of water that would otherwise accumulate over the beds ; and, thus retaining the air clear and dry, allows the full operation of the other causes, particularly radiation.

T. A. WISE

\section{NOTES}

The Academy of Sciences in Paris publishes the following telegrams received from M. Janssen. One dated Ootacamund, I8th December, In $6^{\mathrm{m}}$ P.M., says : "Great hydrogenous atmosphere very rare beyond "chromosphere." The other, received on the rgth December by the Minister of Public Instruction, but not dated, simply,says : "Eclipse observed ; important results." The Royal Academy of Sciences at Amsterdam has received the following telegram from one of its members, Dr. Oudemans, of Batavia:- "Preliminary results : Corona distinctly seen, pure white rays, dark rifts as far as the moon's limb; no outline of chromosphere; radial polarisation of Corona ; no magnetic disturbances ; moving shadows positively observed."

Ax the meeting of the French Academy, held on Saturday last, to fill up the four vacant chairs, $M$. Thiers, $M$. de Remusat, Minister for Foreign Affairs, and M. Dufaure, Minister of Justice were present and voted. The first election was for a suc- cessor to Montalembert, and the Duc d'Aumale received 28 votes, one blank vote being recorded. For M. Villemaine's chair there were three candidates, M. Littré, who obtained I7 votes; M. Taillandier, 9 ; and $M$. de Viel Castel, 3. There were six candidates for $M$. Prévost-Paradol's chair. M. Camille

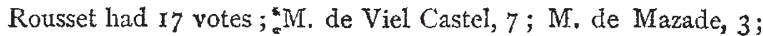
M. de Lomenie, I ; M. Taillandier, 1 ; and M. Mary-Lafon, O. The choice of a successor to Prosper Mérimée was only made after two ballotings. At the first essay M. Edmond About obtained 13 votes; M. de Lomenie, $13 ; \mathrm{M}$. de Viel Castel, 2; M. de Mazade, I; and M. Mary-Lafon, O. At the second ballot M. de Lomenie received 15 votes, and M. Edmond About I4. Previous to the election a protest in the form of a lengthy pamphlet was distributed among the Academicians by the Bishop of Orleans, who, while professing the utmost respect for the personal character of M. Littré, declared that now, as in 1863 , he opposed the admission into the Academy of one who in his writings was the defender of Materialism, Atheism, and Socialism. We learn that in consequence of M. Littré's election, Monseigneur Dupanloup has resigned his seat in the Academy.

WE greatly regret to hear of the death, announced by telegram, from choleraic diarrhœea, of the Venerable John; Henry Pratt, M.A., Archdeacon of Calcutta. $\mathrm{He}$ was educated at Caius College, Cambridge, where he took his B.A. degree in 1833 , when he was third wrangler, the Masters of Christ's and Sidney Sussex Colleges being also wranglers, with Dr. Boustead, afterwards Bishop of Lichfield. In 1838 he was appointed to a chaplaincy in connection with the East Indian Company, and in I850 was nominated to the Archdeaconry of Calcutta, which he held up to the time of his death. He was well-known for his researches of the interior structure of the earth, and had been a frequent contributor to our columns.

Dr. Gustav Radde, Director of the Natural History Museum at Tiflis, has just returned to that town from an interesting journey to the head waters of the Euphrates. Mr. H. E. Dresser has received a letter from him, dated Tiflis, Dec. 14, from which we translate the following extract, viz. :- "Early in August I as cended, in company with Dr. Siewers, a young geologist, the Great Ararat, and we reached an altitude of $I_{4}, 233$ feet above the sea level. Our journey extended over three months, and we have brought back a splendid botanical collection, many good insects, and geological specimens. You will read full particulars ere long in Petermann's 'Mittheilungen.' As regards ornithology, I have not, I am sorry to say, time now to write further respecting the good materials we gathered together, and am just leaving home for another month."

The Professors to the Newcastle-on-Tyne College of Physical Science have determined to institute evening classes, to commence immediately after the winter vacation, for the purpose of giving instruction in their respective subjects to persons who are unable to attend their day classes. The Professors wish it to be understood that the instruction given in these classes will be such as to require a certain amount of real study on the part of those who attend them.

The Curator of the Clifton College Museum, Mr. Barrington Ward, has issued a circular asking for donations, to which we are glad to call attention. The following extract will show the very wise limitation placed on the acceptance of specimens :"It has been decided, with the approval of the Head Master, that the museum shall be essentially a British one, and shall illustrate the natural history and antiquities of our land by good specimens, systematically arranged, under the departments of zoology, botany, geology, mineralogy, and archæology. In addition to this there will be a collection of rare and curious objects, derived from all sources, which may be considered useful for the purposes of scientific teaching, and a large typical 